\title{
The perception of managers about hospital modernization
}

\author{
A percepção dos gestores acerca da modernização hospitalar \\ La percepción de los gestores sobre la modernización de los hospitales
}

Received: 02/04/2022 | Reviewed: 02/09/2022 | Accept: 02/13/2022 | Published: 02/20/2022

Emerson Pessoa Vidal

ORCID: https://orcid.org/0000-0001-9906-030X Federal University of São Paulo, Brazil

E-mail: e.vidal@unifesp.br

Márcia Mello Costa De Liberal

ORCID: https://orcid.org/0000-0002-2589-1802 Federal University of São Paulo, Brazil

E-mail: deliberal@uol.com.br

Paola Zucchi

ORCID: https://orcid.org/0000-0002-7749-8033 Federal University of São Paulo, Brazil E-mail: pzucchi@unifesp.br

\begin{abstract}
This paper seeks to assess the perceptions that healthcare managers have about the efficiency, efficacy, and effectiveness of traceability tools and Internet of Things (IoT) technologies in hospitals in the city of São Paulo. This is an exploratory observational study, with a transversal cut, in which samples were collected from 25 hospitals in the city of São Paulo, which responded to the Likert questionnaire comprising questions about the advantages and disadvantages of the use of traceability tools under the view of health managers. For the analysis, qualitative and quantitative evaluations were carried out, with comparisons of normality and test of mean comparisons between the data got. The results show that a significant portion of the hospitals make use of traceability tools, pointing out its use as fundamental for the execution of processes in an effective and efficient way. Although the use of such tools implies in higher quality and control of the institutions, it is still incipient in Brazil. However, the tools curb the error and increase the quality of health services and patient care. The use of traceability tools and IoTs is becoming more and more widespread all over the world and it becomes urgent that the awareness about their real effectiveness is thus gained. The managers' evaluation sheds light on the efficiency, efficacy, and effectiveness of such tools, and how its use is a tool of unparalleled importance in managing processes and minimizing errors that often occur in dealing with the patient.
\end{abstract}

Keywords: Internet of things; Traceability tools; Perception; Efficiency; Efficacy; Effectiveness.

\section{Resumo}

Este documento busca avaliar as percepções que os gestores de saúde têm sobre a eficiência, eficácia e efetividade das ferramentas de rastreabilidade e das tecnologias da Internet das Coisas (IoT) nos hospitais da cidade de São Paulo. Trata-se de um estudo observacional exploratório, com um corte transversal, no qual foram recolhidas amostras em 25 hospitais da cidade de São Paulo, que responderam ao questionário Likert compreendendo perguntas sobre as vantagens e desvantagens da utilização de ferramentas de rastreabilidade sob o ponto de vista dos gestores de saúde. Para a análise, foram realizadas avaliações qualitativas e quantitativas, com comparações de normalidade e teste de comparações médias entre os dados obtidos. Os resultados mostram que uma parte significativa dos hospitais faz uso de ferramentas de rastreabilidade, apontando a sua utilização como fundamental para a execução de processos de uma forma eficaz e eficiente. Embora a utilização de tais ferramentas implique uma maior qualidade e controle das instituições, ela ainda é incipiente no Brasil. No entanto, as ferramentas limitam o erro e aumentam a qualidade dos serviços de saúde e dos cuidados aos doentes. A utilização das ferramentas de rastreabilidade e das IOT está a tornarse cada vez mais generalizada em todo o mundo e torna-se urgente que se ganhe assim a consciência da sua real eficácia. A avaliação dos gestores lança luz sobre a eficiência, eficácia e efetividade de tais ferramentas, e como a sua utilização é de uma de importância ímpar na gestão de processos e na minimização de erros que frequentemente ocorrem ao lidar com o paciente.

Palavras-chave: Internet das coisas; Ferramentas de rastreabilidade; Percepção; Eficiência; Eficácia; Efetividade.

\section{Resumen}

Este trabajo pretende evaluar las percepciones que los gestores sanitarios tienen sobre la eficiencia, eficacia y efectividad de las herramientas de trazabilidad y las tecnologías del Internet de las Cosas (IoT) en los hospitales de la ciudad de São Paulo. Se trata de un estudio observacional exploratorio, de corte transversal, en el que se recogieron 
muestras en 25 hospitales de la ciudad de São Paulo, que respondieron al cuestionario tipo Likert, compuesto por preguntas sobre las ventajas y desventajas del uso de las herramientas de trazabilidad desde el punto de vista de los gestores sanitarios. Para el análisis, se realizaron evaluaciones cualitativas y cuantitativas, con comparaciones de normalidad y pruebas de comparación de medias entre los datos obtenidos. Los resultados muestran que una parte significativa de los hospitales hace uso de las herramientas de trazabilidad, señalando su uso como fundamental para la ejecución de los procesos de forma eficaz y eficiente. Aunque el uso de estas herramientas implica una mayor calidad y control de las instituciones, todavía es incipiente en Brasil. Sin embargo, las herramientas limitan los errores y aumentan la calidad de los servicios sanitarios y la atención al paciente. El uso de las herramientas de trazabilidad y de la IO está cada vez más extendido en todo el mundo y es urgente conocer su eficacia real. La evaluación de los gestores arroja luz sobre la eficiencia, la eficacia y la efectividad de dichas herramientas, y cómo su uso tiene una importancia inigualable en la gestión de los procesos y en la minimización de los errores que suelen producirse en el trato con el paciente.

Palabras clave: Internet de los objetos; Herramientas de Trazabilidad; Percepción; Eficiencia; Eficacia; Efectividad.

\section{Introduction}

The advance of Information Technology (IT) in our society is notorious and is constantly evolving. Information obtained quickly through systems and devices that allow institutional excellence is, without a doubt, one of the pillars of organizations. In the health sector, however, computerized systems can mean the difference between life and death, since information is often the core of patient care and the cornerstone of solving problems.

Computerized systems not only assist in business competitiveness but also contribute to the improvement of care for the community in a service of basic necessity. According to the author, secure systems need to be applied in healthcare in order to avoid serious consequences, such as lawsuits or inducing medical error. "It is vital that a computerized system present accurate, complete, useful, and real-time information" (Pereira et al., 2012).

Nowadays, the technology that is gaining more and more space in society is the Internet of Things (IoT), which, because of its potential applicability in various sectors, has become the focus for industry and commerce (Ilin et al., 2018). In healthcare, IoTs are an emerging theme in building efficient processes and smart hospitals that not only add value to the services offered but also quality. By enabling greater reach in diagnosis, treatment, management, and decision-making, IoTs are the new foundation in terms of process efficiency, imparting confidence to the physician and safety to the patient (Liu et al., 2018).

Studies on the quality of care in hospitals reveal that this sector already faces many challenges, including rising operating costs and high numbers of medical errors, and of course a gradually aging population, which has intensified in recent years. (Wamba et al., 2013).

For Infante et al., (2007), the healthcare organization is defined as a productive system of care where the supply sector is integrated as a subsystem to meet the needs of inputs and equipment. Material selection and inventory management, in which the materials used in the hospital are defined and ways to monitor consumption levels that allow the scheduling of their acquisition and distribution, are critical processes for the organization, highlighting the interface between clinical professionals and the supply sector as critical to the organization (Infante et al., 2007).

According to Metzner, Silva, and Cugnasca (2017) traceability can be defined as an identification system that allows to rescue the origin and the history of the product in all stages of the supply chain, which goes from the production of the raw material to the use by the final consumer. There are a series of technologies that can ensure the product traceability, together with quality processes, such as barcodes, QR codes (Quick Response), radio frequency identification (RFID), card technology, iBeacons (Indoor Proximity System), NFC (Near Field Communication), barcodes, among others (Metzner et al., 2017).

Within logistics, traceability interferes directly in the quality of patient care. Error reduction made possible by an intelligent system reflects directly on the user's safety, once it is possible to significantly reduce human interference in the checking and information capture processes. In the case of medication, this is achievable because it is possible to follow the 
process of receiving the medication until it is administered to the patient, which ends up minimizing doses or wrong medications. In addition, IoTs denote a possible holistic view of institutions and their processes, which can contribute to the quality of care. Thus, this study seeks to investigate the perception that health managers have about traceability tools and IoTs technologies in hospitals in the city of São Paulo.

\section{Theoretical fundaments}

\subsection{The management and quality of attendance}

Quality is an abstract concept, easy to describe, but difficult to operationalize. La Forgia and Couttolene (2009) state that excellent health care depends on country-specific standards that are set by regulatory agencies and are constantly changing. Portela (2000) states that quality is structured in three components: structure, process, and outcomes, and that these components have become the cornerstone of quality assessment instruments and standards around the world. Thus, the evaluation of structure comprises the evaluation of the competence of the service providers, including health units, equipment, human resources, and financing (Salu, 2013; Portela, 2000). Process evaluation includes the analysis of the service production process itself, ideally based on evidence. Outcome evaluation focuses on identifying the end products of service production, usually specified in terms of health, safety, or patient satisfaction (Branco, 2020; La Forgia et al., 2009).

Aside from the health consequences for patients, poor quality also generates large unnecessary costs that ultimately threaten the economic viability of the health care system. Thus, inferior quality is associated with increased expenses. In countries like the United States, where there is a clear literature contribution regarding the relationship between quality and costs, low quality - indicated by overuse, underutilization, errors, adverse events, misplaced information, diagnostic and procedural repeats, and readmissions - results in lost income for individuals and higher health care expenses (La Forgia \& Couttolene, 2009). In addition, the higher the quality of a hospital, the greater its financial return, which brings as a result more capital to reinvest in the institution itself, thus enabling a process of continuous improvement (Ramos et al., 2018).

The search for quality within the hospital environment is a guideline that requires constant improvement. However, some technological tools may facilitate the application of these rules described above, allowing the health unit to position itself to meet the most contemporary quality requirements. Not that the tools will be a miracle solution, but they act as facilitators of the quality processes. Thus, according to the IOM, systems can facilitate the application of scientific knowledge of quality medical practice and practice through tools that support the delivery of consistently safe evidence-based care. (Committee on Quality of Health Care in America, 2001).

The debate surrounding the quality of health care is now an essential and necessary issue in medical circles, in the governmental sphere, and for users of the health care system.

\subsection{Process management tools and innovation in healthcare}

Traceability and Internet of Things (IoT) tools, despite their usefulness, have only recently gained visibility in the medical landscape. To get an idea, the European Federation of Medical Informatics (EFMI) created in 2006 its working team entirely dedicated to traceability research in healthcare (Pinto C. P., 2016). In Brazil, the efforts are equally recent; the initiatives regarding the law of traceability of medicines began in 2004 in order to expand patient safety and repel counterfeit drugs, and is still in the implementation phase, which should occur definitely according to ANVISA's estimates around 2021.

The drug traceability law actually began with the creation of the National System of Drug Control (SNCM) as the promulgation of Law 11.903/2009. The legislation at the time proposed that, by traceability technology, the history, current custody or last known destination of the drugs could be traced. Since then, much has been debated and deadlines have been 
extended, once industry players have objected to certain parts of the project's execution and to the new Law no. 13.140, of December 2016, which establishes a maximum deadline of five years for the pharmaceutical chain to implement this technology in order to integrate to SNCM.

The construction of intelligent processes and hospitals underlies the use of traceability and IoTs, which are based on the use of devices and sensors connected to the internet, allowing the manager not only to control the processes but also to intervene when deemed necessary. Through connected sensors, patients are monitored in real time, which allow nurses and doctors, even remotely, to get vital data such as blood pressure, blood glucose, oximetry, location within hospitals and even limit access to prohibited sectors (Moura et al., 2020).

\subsection{Efficiency, efficacy and effectiveness, evaluative dimensions of health}

According to Leal (2017) efficiency is related to the method, that is, the right way of doing things. An efficient company is one that achieves its production volume with the least possible expenditure of resources, so that the cost is the lowest per unit produced. Effectiveness, on the other hand, would refer to results, to products resulting from an activity. It is the choice of the right solution for a problem or need. Thus, an efficient company puts on the market the desired volume of the right product for a need (Leal, 2017; Nunes, et al., 2013; Bio, 1996).

For Pinto and Coronel (2017), efficiency and effectiveness are topics that evaluate the performance of any organization, as well as the expectations of users and people who hold the resources during the process of manufacturing or creating a product or service. Both efficiency and effectiveness are divergent in that they are not synonymous and do not have the same connotation in the administrative area. In fact, there can be efficient and inefficient organizations and inefficient and effective organizations. The convergence of the theme follows the idea that the ideal is that these two terms are aligned in the management of organizations due to their close relationship, because it is the function of management to ensure the efficiency and effectiveness of organizations together. Thus, with the use of the best means, that is, efficiency, one will always seek to achieve the best possible results, that is, effectiveness (Pinto et al., 2017).

Effectiveness, in turn, refers to the examination of the relationship between implementing a program and its affects and/or results, "its success or failure in terms of an effective change in the previous social conditions of the lives of the populations affected by the program under evaluation (Frasson, 2001). The evaluation of effectiveness is essential in the sen se that the project may achieve its objectives (effectiveness) and the resources may be applied appropriately (efficiency), without the project responding to the needs or causing real changes in the target audience (effectiveness). Hence the need to create mechanisms that make it possible to evaluate the impact of the projects developed (Frasson, 2001).

\subsection{Efficiency, efficacy and effectiveness, evaluative dimensions of health}

The consequences of patients' health and quality are directly related to the health system's propensity to offer a service considered being efficient. The redesign of organizations and their processes is seen by various authors as the summit for an institution to have added to itself a condition of excellence and greater capacity in performing its functions (Pinto \& Coronel, 2017).

Considering that the measurement of efficiency, efficacy and effectiveness are notoriously quality and productivity indicators of a management, and that quality indicators measure the total of errors, nonconformities or deviations that happen in a process in relation to what was produced and productivity indicators deal with the use of resources for the generation of products and services that are very important, since they allow an accurate evaluation of the effort employed to generate products and services (Sano et al., 2013; Frasson, 2001; Maximiano et al., 2017). 
The aim of this study is to analyze the efficiency, efficacy, and effectiveness of traceability tools such as barcodes, RFID, card technology, and QR CODE, through the manager's perception of their use in the hospital system. Traceability tools have become one of the most important components for the optimization of various processes in the industry (Sonda, 2018). In laboratory and healthcare sectors, the application of this tool has been conquering the market not without some success (Jones \& Jackson, 2016). The big question is whether managers feel comfortable with such tools in their daily practices. Thus, according to the discussion above, the following hypothesis is suggested:

H1: The use of traceability tools positively influences process management in healthcare.

The computerization of health sectors has been increasingly present, which for many means the attribution of a unique utility regarding its adoption. In this sense, such equipment and tools cease to be accessories and become an integral part, giving it a fundamental position, which for many means a better quality in services (Van Ornum, 2018). This discussion leaves room for employing a search for the manager's discourse and what the use of traceability tools and IoTs mean in everyday life. Thus, according to the above discussion, the following hypothesis is suggested:

H2: Traceability tools as an active constituent part of IoTs are a valuable addition to the quality of hospital processes.

The pharmacy for dealing with high-value products, fragility and high turnover leaves room for errors and adulteration (Pokorny, 2017; Herranz et al., 2018; Silva et al., 2018). Likewise, the dispensing of medication, patient care, and the administration of beds and equipment are subject to human irregularities in ways that express process failures (Machado, 2018). Thus, according to the above discussion, the following hypothesis is suggested:

H3: Sectors such as pharmacy and nursing have added the factor of efficiency, efficacy and effectiveness to their processes when using traceability tools.

An emblematic fact is that of computerization as a factor in reducing human errors in the performance of tasks. The lack of adequate communication between the attendants, nurses and doctors can lead to primary errors that harm the patient (Souza et al., 2020). Thus, it is believed that reducing or restricting the human factor can lead to better performance in hospital processes, since it enables the manager to have greater control and to determine possible failures (Dias, et al., 2010). Thus, it is believed that reducing or restricting the human factor can lead to better performance in hospital processes, since it enables the manager to have greater control and to determine possible failures.

H4: The more automated the system is, the more efficiency, effectiveness, and efficacy is added to the processes.

\section{Methodology}

The study was cross-sectional, allowing the researcher to understand what IoTs and traceability tools meant for the healthcare manager. Cross-sectional is a photograph or snapshot of a population through sampling, examining the members of the casuistic or sample for the presence or absence of exposure and the presence or absence of the effect.

The questionnaires were prepared through a pre-test with five large hospitals in the State of São Paulo. After answering the questionnaires, the managers returned them with an opinion about the questions they considered redundant, irrelevant, inconsistent and not objectively related to the specific purpose of the research. After the validation test, a team composed of professionals in health management and economics met to judge the pertinence of the managers' opinions. Three interviews were also held in order to clear up any doubts regarding the points made by the respondents. After this process, the questionnaire was closed. Although the questionnaire was not got directly from any source, but was created by the research team, its theoretical foundation was based on the theoretical conceptual basis of authorities in health management.

The study sample was composed of private and public general hospitals in the municipality of São Paulo. In 2018, the municipality of São Paulo had 147 general hospitals, according to a survey conducted at the Ministry of Health, in Brazil's 
National Register of Health Establishments (CNES). Of these, 71 were of large and special size, which were selected to compose the research. The sample totaled 25 hospitals of special and large size. The study covered the period from 2017 to December 2020. And the hospital managers (superintendents, managers, administrators) or someone designated by them to be responsible for the hospital were interviewed.

To obtain the data we used a survey questionnaire with a Likert scale, where there were multiple choice questions graduated on a scale from 1 to 5 points, which included the following categories: "strongly disagree" (1), "somewhat disagree" (2), "neither agree nor disagree" (3), "somewhat agree" (4) and "strongly agree" (5). These questionnaires sought to gauge whether, in the manager's view, the use of traceability technologies was providing advantages and/or disadvantages in performing their tasks, that is, the efficiency, efficacy and effectiveness of the device. The Likert data analysis comprised a series of procedures involving descriptive and inferential statistics. For the calculation, a measure of central tendency was used in which the answers were gathered and from which the most frequent was obtained, which made it easier to interpret the answers.

As a way to evaluate the statistical consistency of these differences, mean and median comparison tests were adopted. The means of each pair of items were compared using the one-way analysis of variance (ANOVA) test. The research used ANOVA analysis of variance for the purpose of testing for significant differences between the means. ANOVA is a technique for partitioning the total variance into one or more plots, relating to the factors (independent variables) that can be identified as having an effective influence on the response (dependent variable) and yet another, relating to the random error added to the uncontrollable variables. When significance was evident in the ANOVA, a Bonferroni post-hoc test was performed to distinguish where specifically the differences were.

As a further exploration, the correlation between variables was extracted by Pearson's parametric correlation coefficient. For the effective analysis, besides the variables of the Likert questionnaire, the questionnaire was divided into questions that referred to efficiency, efficacy, and effectiveness. Thus, in the analysis, the various questions could be grouped in order to build a measurement index of the institutional characteristics.

It is worth mentioning that in the literature the Likert questionnaire measurement is much debated about the use of standards, which here were adopted according to Boone $\mathrm{Jr}$ et al., for whom the most representative measures of the questionnaire in question are the mean, standard deviation, Pearson's correlation and ANOVA. In possession of this information, we proceeded with the construction of the results (Boone Jr. et al., 2012).

To calculate the efficiency, efficacy and effectiveness, a series of questions was analyzed, from which we calculated the average, the standard deviation and the maximum and minimum of the distribution and its normality. The set of questions of a specific nature for each evaluation modality (efficiency, efficacy and effectiveness) gave rise to the data. Specifically, the questionnaire was divided into two parts, of which half corresponded to efficiency, and the other half to effectiveness. The combination of the questions about efficiency and efficacy gave rise to the measure of effectiveness, which according to Sano and Filho (2013), is the sum of doing what has to be done (efficiency), with the results achieved (effectiveness) plus the quality that generates the institutional transformation (effectiveness).

\section{Results}

\subsection{Qualitative Analysis}

The population of the surveyed hospitals resulted in 71 contacted hospitals. Of these, 25 (35\%) answered the questionnaire and the free and informed consent form, 17 (68\%) had traceability tools and 8 (32\%) said they did not have traceability tools. Thus, the sample of hospitals was investigated under a confidence level of $95 \%$, with a margin of error 
(sampling error) of $10 \%$. Among the 25 hospitals investigated, $68 \%$ make use of traceability tools and $32 \%$ stated they do not.

Figure 1: Institutions using tools or IoTs.

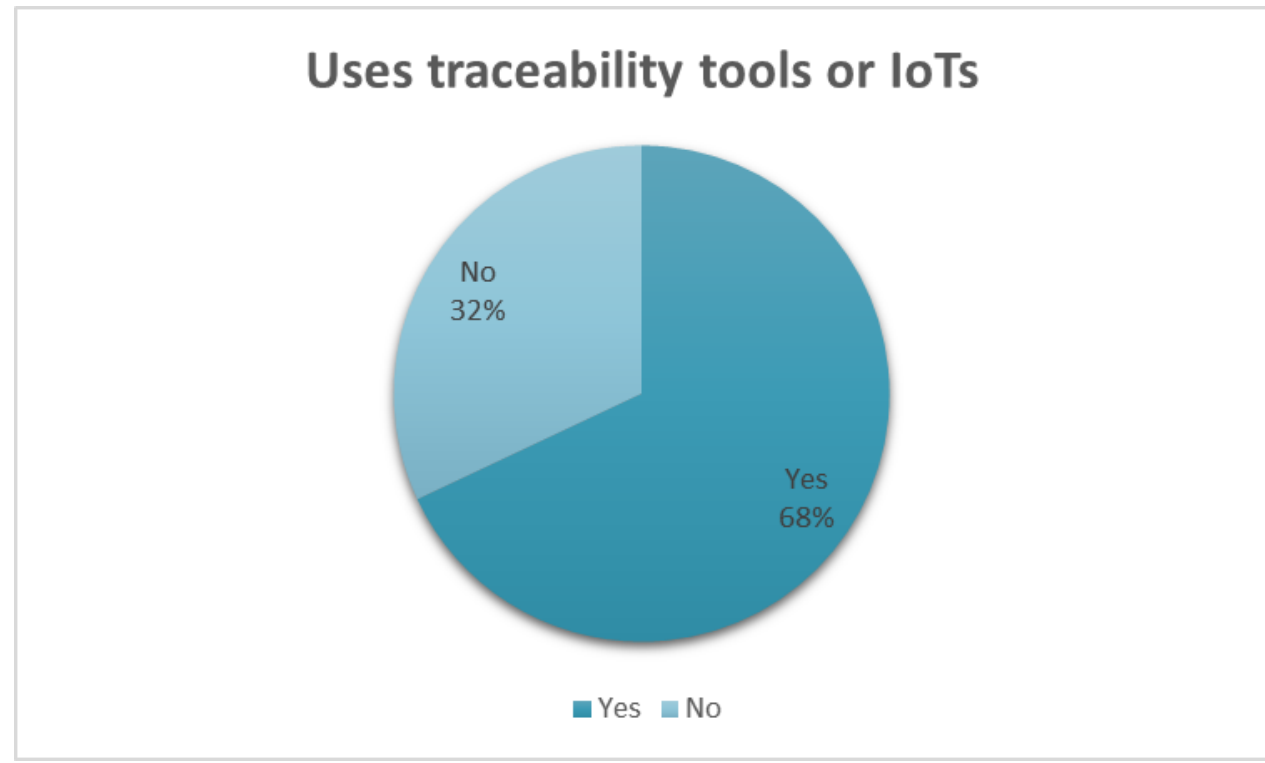

Source: Authors (2021).

The hospitals that declare they don't have traceability tools $38 \%$ blamed the lack of investment and the lack of public policies as the main reason for not adopting them, a reason mainly linked to hospitals that depend on projects and implementation by the state. The data can be visualized in Figure 2.

Figure 2: Reasons for not using a traceability tool or IoTs.

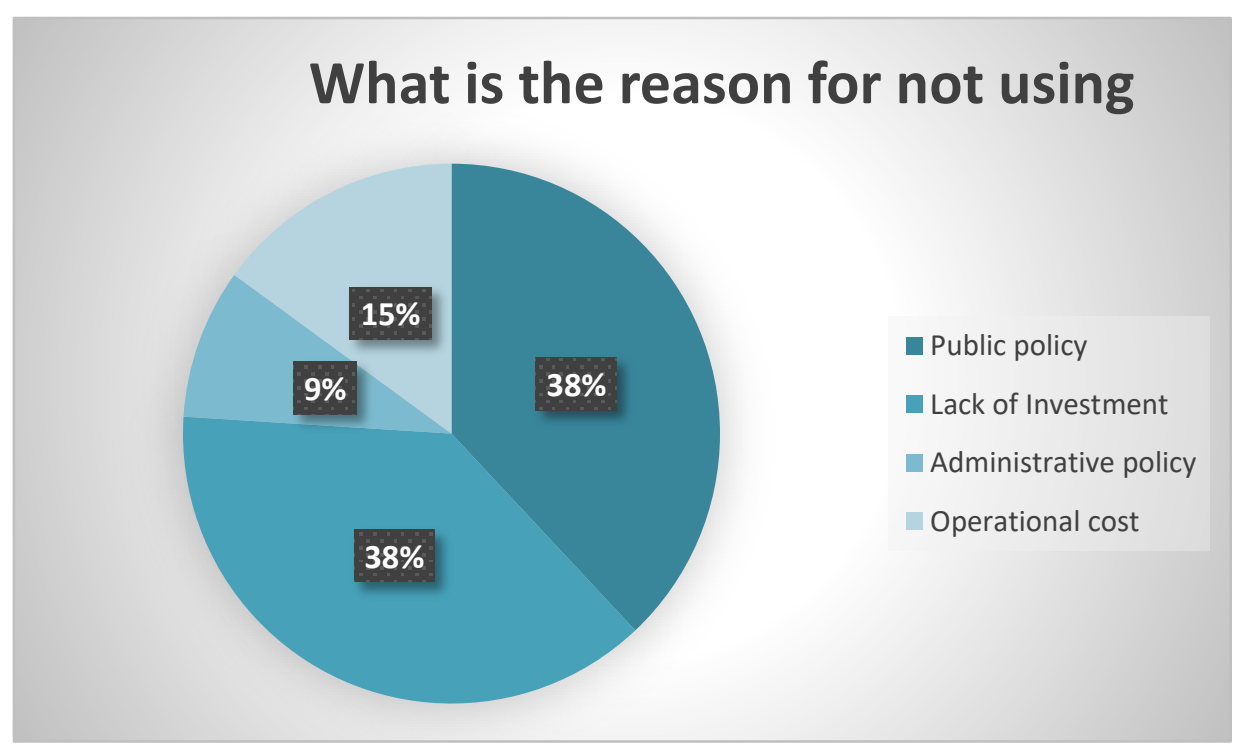

Source: Authors (2021).

When it comes to operational cost, the results show that while a sizable portion (41\%) agree that such tools reduce cost, another portion believes that there is no change in the cost result when implementing traceability tools (41\%). And a smaller portion disagrees about the reduction (18\%), Figure 3. 
Figure 3: There was a reduction in operating costs.

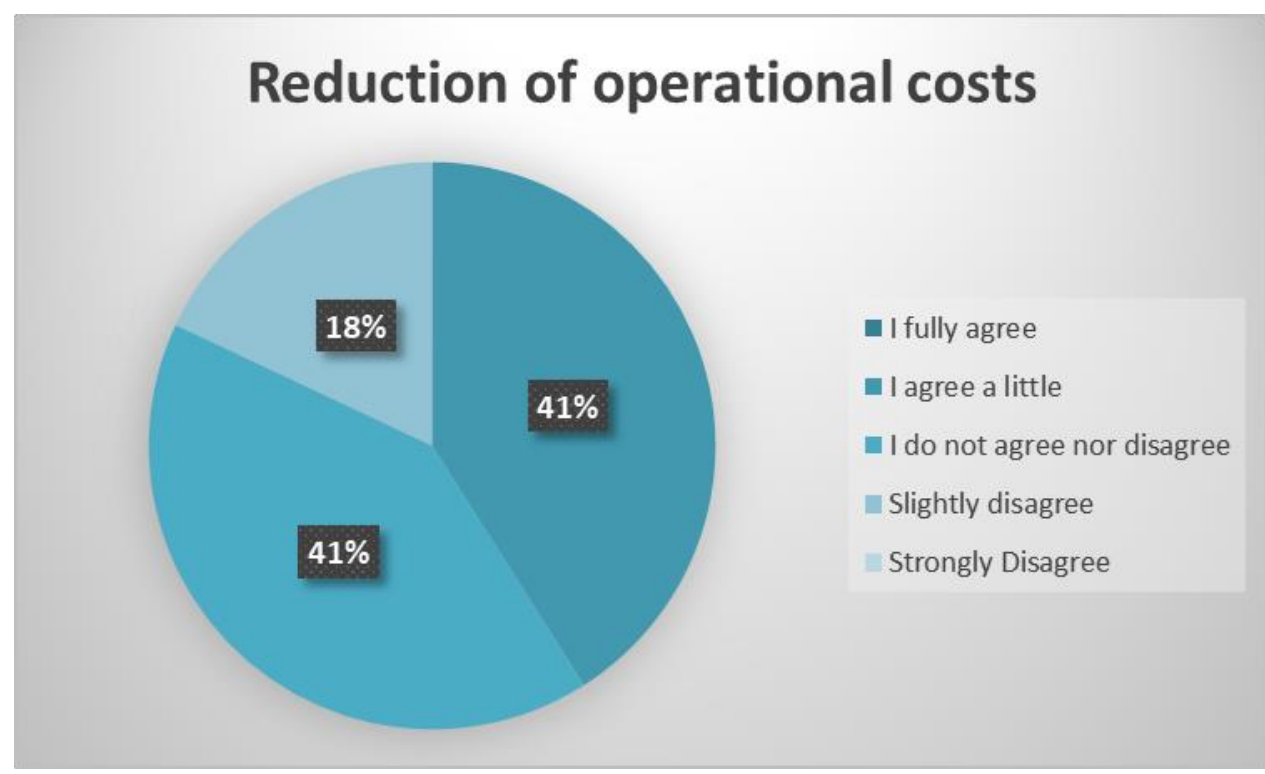

Source: Authors (2021).

The screening process after the use of tools, according to the managers, has become more organized and of higher quality. According to the data, $47 \%$ totally agree and $47 \%$ somewhat agree, totaling $94 \%$ of confirmation of the process streamlining, Figure 4.

Figure 4: Improvement of patient screening processes and location of medical records

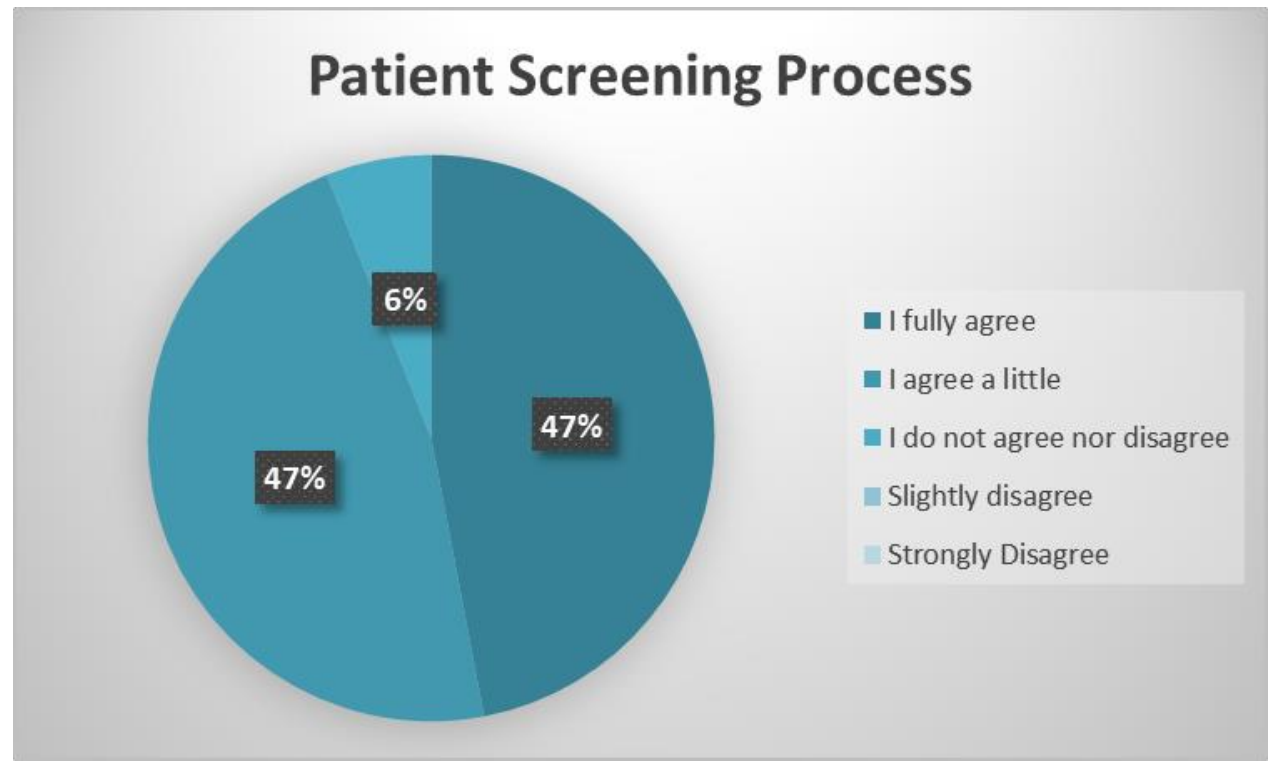

Source: Authors (2021).

Regarding bedside checking, this has proven to be an important tool for institutions that use traceability tools. With $65 \%$ of the participants saying that these processes are benefited by the technologies. Only $6 \%$ said they did not agree with the improvement in checking, Figure 5. 
Figure 5: Bedside checking has become more effective.

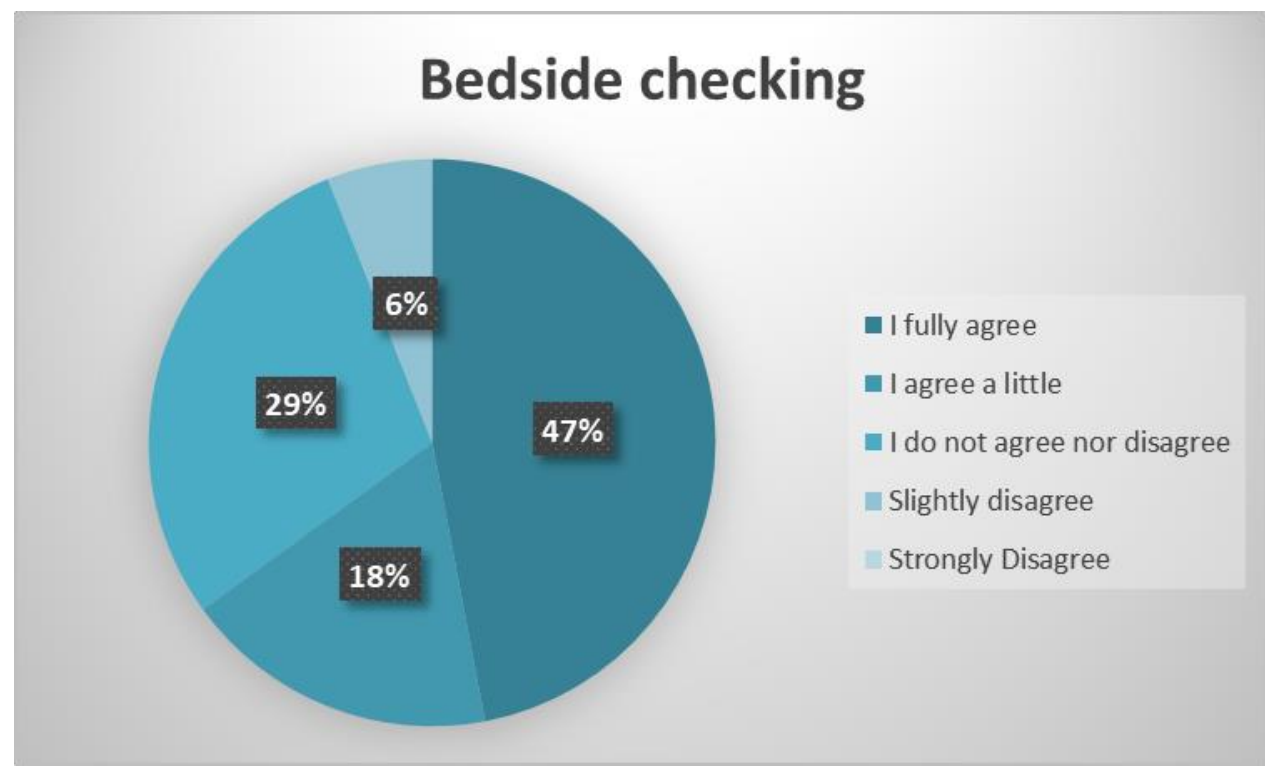

Source: Authors (2021).

With regard to the patients' increasing satisfaction with the technologies, the data clearly show that $59 \%$ of the total contingent are satisfied, and $35 \%$ demonstrate neutrality with regard to this question and only $6 \%$ disagree with the efficiency, see Figure 6:

Figure 6: Patient satisfaction regarding the technologies.

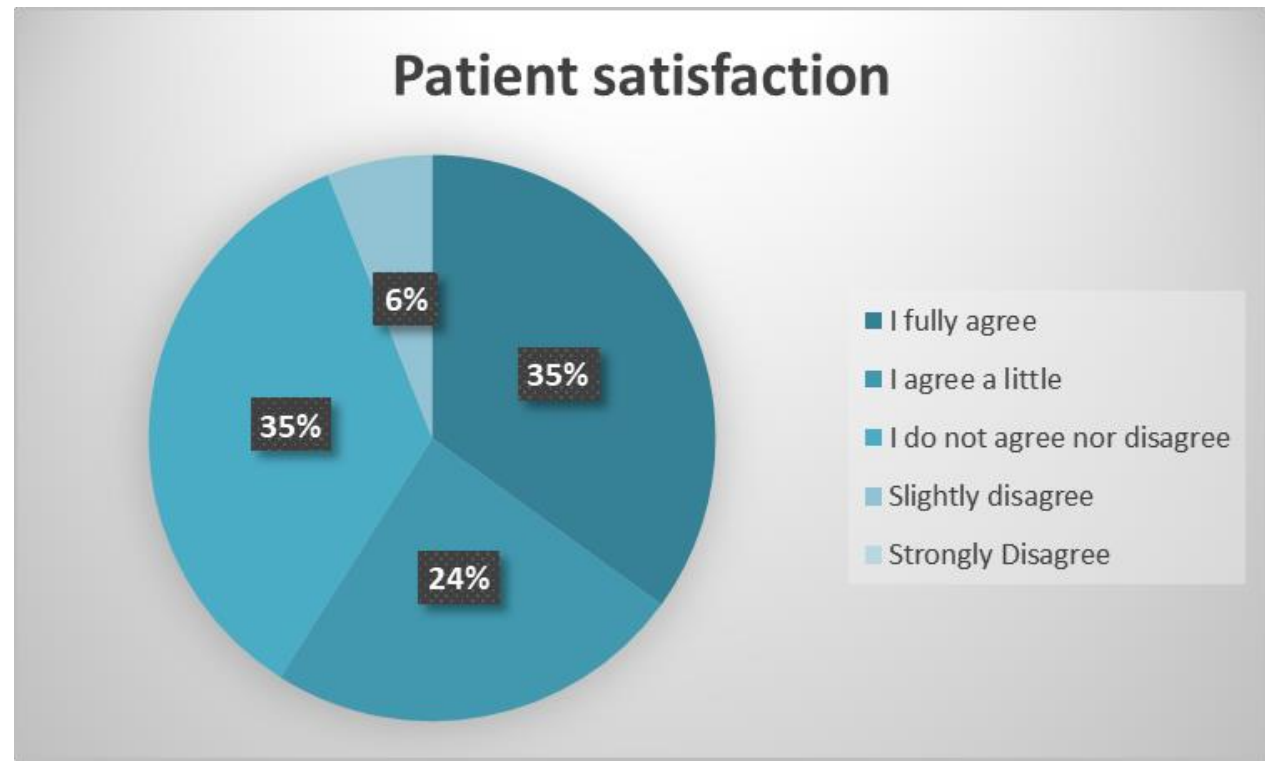

Source: Authors (2021).

For the hospital management, the use of traceability tools can be seen as an option that yields results from the financial point of view, positively impacting the profits that the institution believes it has. A measure of the financial benefits evaluated by the questionnaire was the ROCE (return on invested capital), which, in a simplified way, serves to measure how much the result is divided by the staff, thus it is a metric of total assets minus the short-term debts (current liabilities). It can also be defined as the value of all assets used for business or fixed assets plus working capital (current assets minus current 
liabilities). In this way of measuring the financial impact under the managers' perception, one can say that there is a return on invested capital, since most managers answered that there was a return. About $95 \%$ said they either fully or somewhat agreed with the result. Thus, the tangible assets were enabling a profitable return on each unit of investment, Figure 7.

ROCE is the primary measure of the efficiency with which a company uses all available capital to generate additional profits.

Figure 7: ROCE results.

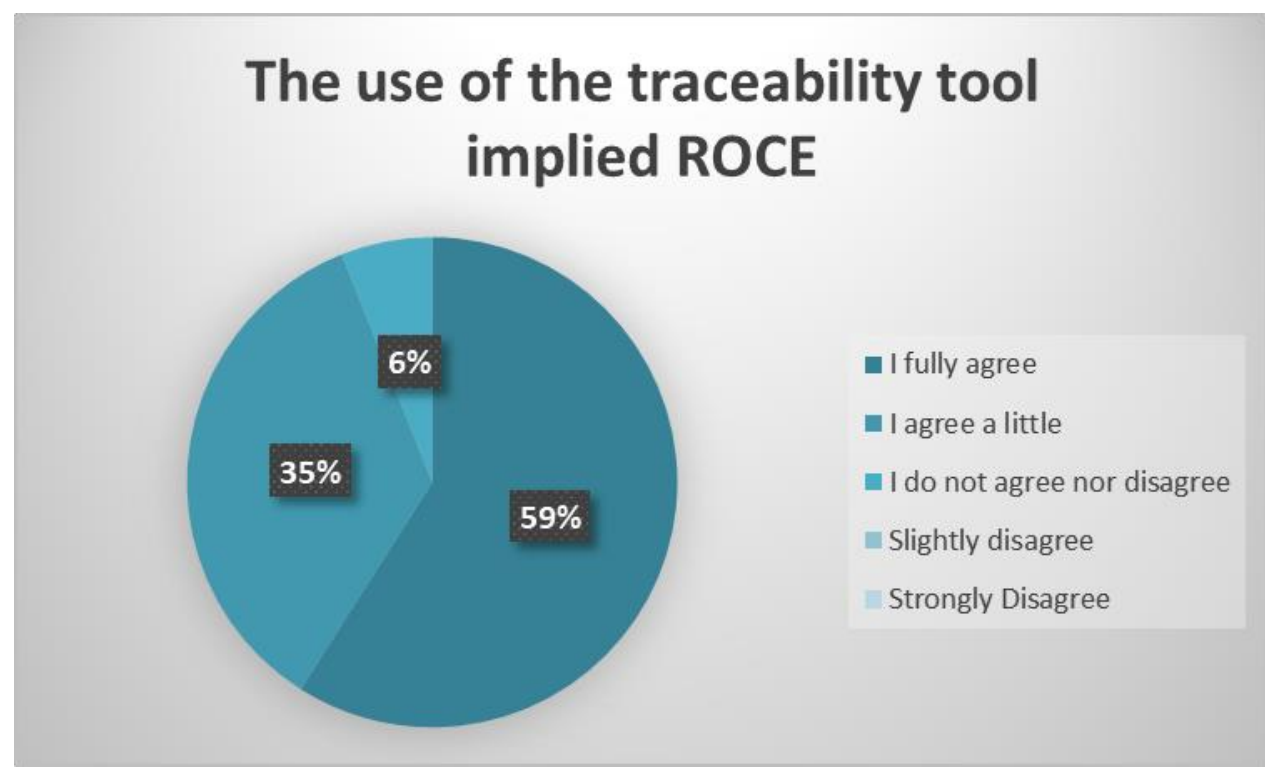

Source: Authors (2021).

The data shows that, for the most part, that $76 \%$ agree that the use of technologies has resulted in ROA and ROE for the institutions. About $23 \%$ stated neutrality and no participants disagreed with the statement, figure 8 .

Figure 8: Financial Gains.

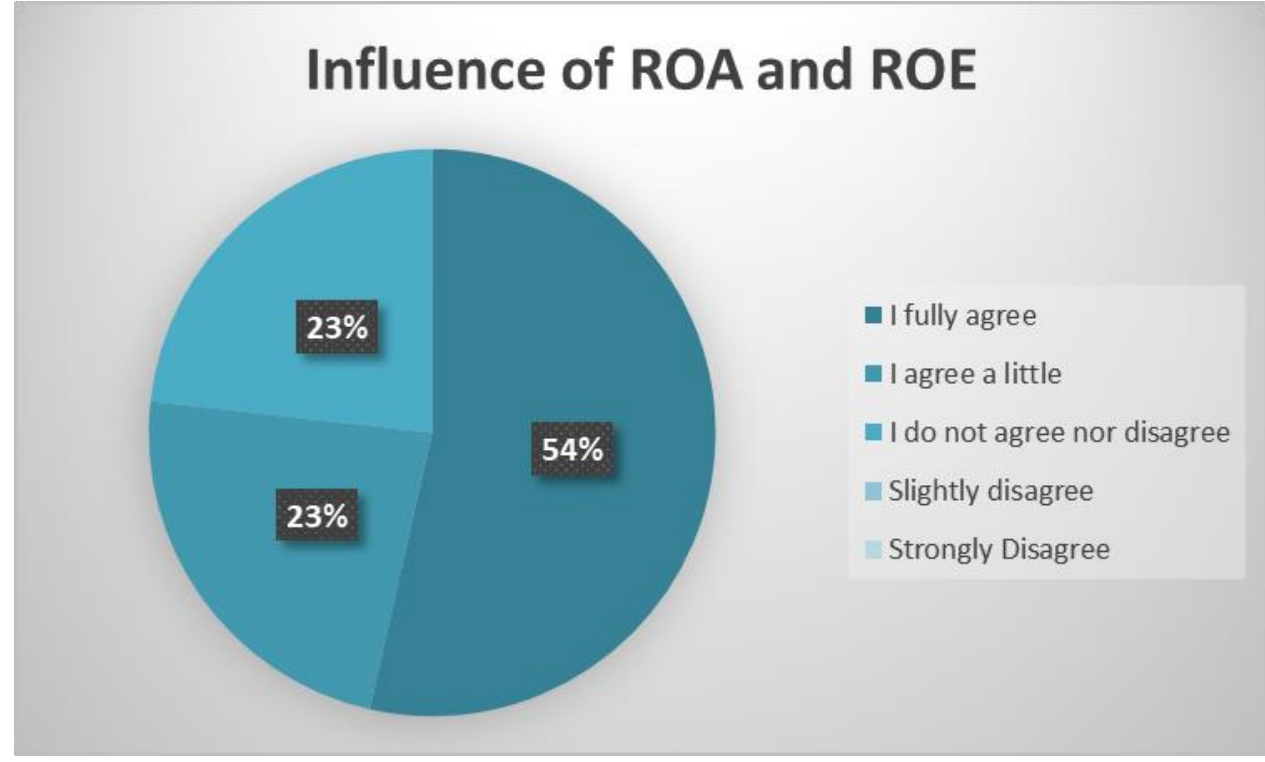

Source: Authors (2021). 


\subsection{Quantitative Analysis}

In the case of the efficiency variable, the calculations obtained through the statistical software SPSS Statistic, version 22.0, concluded through the Shapiro-Wilk test that it was normal, with $\mathrm{p}$ value of 0.09. Likewise, the efficacy variable as well as the effectiveness variable gave a normality pattern in their results with Shapiro-Wilk values of 0.216 and 0.109 respectively, which means that the means, medians of the data represent well the group, having no major deviations.

When the comparison of means test, analysis of variance (or ANOVA) was performed with the variable time of use of the tool, the results were significant for effectiveness with a "p" equal to 0.007, which revealed that there was a strong relationship between effectiveness and time of use. Thus, we can say that these are samples from diverse populations and that the variance was systematic. The post-hoc analysis with the Bonferroni test showed that while 1 to 2 years of use of the traceability tool was not significant for the effectiveness, 2 to 5 years and 5 to 10 years revealed that the time of use of the instrument was important for the effectiveness of the device in the institution.

The Bonferroni multiple comparisons test determined that for the effectiveness variable there was a relationship between the time of use, showing that from 2 to 5 years and from 5 to 10 years there was clearly a significance of $\mathrm{p}=0.022$.

When performing the correction between the variables' effectiveness versus effectiveness and efficiency, the data clearly showed there was a strong positive correlation. For the correlation efficiency and effectiveness, the correlation degree was 0.987 . And for the correlation between efficacy and effectiveness, the index was 0.986 . Both correlations denote a very high correlation that can be established between the variables, which means that the higher the institutional efficacy and efficiency, the higher the effectiveness will be.

Such data evidences that $\mathrm{H} 1, \mathrm{H} 2, \mathrm{H} 3$ and $\mathrm{H} 4$ are equally true and that the null hypothesis can be rejected. The traceability tools and IoTs, such as RFID, barcodes, card technology, NFC, provide a higher quality to the processes, as well as more efficiency, efficacy and effectiveness. Generating a better performance of the users in performing their activities. These data converge with those of Moura, Pitta et al., for whom technologies such as IoTs are primarily holders of the capacity to raise the quality of performance in health (Moura et al., 2020).

It is inconceivable to live today without certain scientific technological resources, since they raise the quality of life (Kumar et al, 2019).

\section{Discussion}

The health system in Brazil faces demands that prevent it from reaching a level of efficiency worthy of the highest organizations. Fundamental challenges that are involved in four key aspects: financing, management, access, and qualification of professionals (Saldiva et al., 2018).

Going through all these aspects, we have processes that are slow, costly, and prone to errors. The consumer of services, the patient, is often faced with an inefficient system in which omission is present and accountability is not always determined for lack of more concrete evidence.

Investigating the way the manager perceives the sensitive situation in which the health system is inserted, one realizes that the lack of efficiency in the processes is a crucial fact for increasing the quality of care and patient safety. Many times, the political issue and the lack of funding is the big problem for the updating of health services and processes.

According to FGV, the investments in Information Technology in health are below the market average, so that, for companies, this reflects in a suffering service of inferior quality. Thus, in 2020, spending and investment by private hospitals was $4.6 \%$ of annual net sales, while the overall average for companies (services, industry, and commerce) was $8 \%$ (Meirelles, 2021). 
And with public hospitals, these investments are even more derisory. In 2018, the federal government allocated only $3.6 \%$ of its budget to this area. According to the World Health Organization (WHO), the percentage is well below the world average, which is $11.7 \%$. These numbers place Brazil in an uncomfortable position 49th in the ranking of the most inefficient countries in health (Saúde Business, 2021).

An important contradiction imposes itself when comparing the data with the research conducted, since, although of massively heavy initial investment, the expenses convert into profits. As denoted by the managers, the losses convert into ROCE and gains from tangibles and intangibles. Studies on tracking technologies and IoTS in healthcare show that if deployed efficiently, ICT can result in improved quality in the delivery of healthcare services, increased safety in patient care, and lower costs because of the elimination of healthcare services deemed unnecessary.

Today, hospital executives, physicians and researchers must recognize the renewing role of technologies in people, processes, organizational culture and procedures in general. Investments in ICT, as well as its use, allow hospitals to develop operational agility in patient health care.

The adoption of traceability tools still depends on public policies that guarantee free access. While this is not happening, the predominance is in the private hospitals that, with a more directed look at the efficiency of their processes, seek to ensure an acceptable standard of quality, although the adoption of more advanced devices is still limited by budgetary issues (Colleti Júnior et al., 2018). Because of financial issues, hospitals prioritize medical equipment, which in its essence is very important, but without the proper organization and streamlining of processes, it ends up hindering the service in an orderly and streamlined manner.

With the help of traceability, it is possible to create a safer and more comfortable environment. In the specific case of RFID, one of the most common uses is to put RFID-tagged wristbands on newborns in the maternity ward to ensure that they are not switched from their mothers, and that they are not taken out of the ward without authorization, so that a beep is activated whenever the RFID wristband is cut or removed without authorization. Other uses include tagging wristbands for unique identification of a patient and their prescription (Bhuptani et al., 2005).

It is quite clear, in Brazil, that hospitals are differentiated as a business model not only because of the peculiarity of helping people who are in a delicate moment and therefore require greater concern for society, but also because quality, which should be one cornerstone for the best care, is often left in the background. When analyzing how developed they are in technology, public hospitals are precariously computerized, and the most computerized ones can be primary, even when compared to the less computerized ones in the private sector. In the private sector, they are basically divided into two blocks: those which are computerized out of obligation and those which use computerization as a factor of competitiveness (Stevan Jr., 2018). These data converge with the data got in the survey, so that it can be seen that the overwhelming majority of private hospitals have traceability tools in their units. However, this is still far behind the health units of other countries, such as the United States, European countries, and even some from Asia.

The great paradox of hospital technology comprises having, on one hand, state-of-the-art technology applied in care processes (patient treatment), especially in diagnostic imaging and surgeries using catheters and micro-video, and on the other hand, rudimentary systems for administration and management (Salu, 2013).

The manager must judge if the quality compensates the budget expense or if the expense is more relevant than the quality factor, so that it overrides a greater investment in health, because it is really expensive and not worth it. The reason a great part of the institutions is still afraid to invest in traceability tools, robust or not, is the fact that there is a conscious or unconscious predominance of an optimistic vision, which values cost savings, because it believes that although the traceability 
tools are a profitable option, the investment may not overcome the expenses once the growth in quality is not followed by a growth in the invoicing that compensates the expenses (Mota et al., 2018).

This is an innocent vision because it links the investment only to immediate profit. In the short term, it may not come back quickly, but thinking long term, there is a glimpse of the return that comes as tangible and intangible. As an example, we can cite the satisfaction of the patient and their families, streamlining processes, greater rigor in institutional control, greater ability to locate items considered essential, controlled movement and restriction, etc. The institutional incrementation with traceability tools allows the managers not only a more effective organization but also a more active and participative inspection, besides which the insurance rate reduction is another factor that adds to the tangibles.

The creation and building of information infrastructure as part of better patient care is one of the critical value factors that can be approached from a strategic standpoint, where reducing errors and improving patient safety become of unparalleled importance. With a more robust and enhanced system, such as traceability tools and IoT devices, one can extend the understanding of what would be an adequate system for care with minimum quality standards or even excellence. The creation of such a system has the advantage of being able to manage the organization's errors, as well as to investigate complaints more effectively, which besides providing a safer system, provides the healthcare entity with a public view of commitment to safety, which benefits and allows the institution to have a better image and accountability of the organization. Having a differential in the market is a favorable point compared to other institutions, which enables greater credibility (Vankipuram et al., 2018; Metzner et 1., 2017).

Although traceability may seem like a purely technical process, it represents more than a patient's right. The custom of containing a history of the path taken ensures, at least as far as medication is concerned, that the hospital intern will receive the right medication, in the right dose, at the right time, on the right route. Today, health care faces serious adversities in terms of medication control, whether it is in guaranteeing authenticity or its correct application (Silva, et al., 2019).

In the United Kingdom, medication errors by omission, i.e., the non-administration of a medicine needed by the patient or an altered dose, accounted for $17.1 \%$ of medication errors reported to the National Patient Safety Agency. For the pharmaceutical industry, and also for the consumer, another dangerous point is the growing sale of counterfeit drugs. Some estimates show an increase of over 90\% since 2005, with sales of \$75 billion. In places like Latin America, Southeast Asia and Sub-Saharan Africa, more than 30\% are counterfeit, and on the Internet, 50\% of medicines are illegitimate. (Silva, et al., 2019).

The errors committed in caring for a person can occur because of human or system errors. The human approach is of long standing because of unsafe acts that come to cause harm to people, namely nurses, pharmacists, surgeons, anesthesiologists among others, carelessness for a variety of reasons, ranging from recklessness to aberrant mental processes. The errors in the system arise due to the fragility of the system, which can be fallible (Sousa et al., 2019).

The deployment of IoT technologies in institutions as benefits, management optimization, improved use of resources, as well as transparency and greater control in real time (Metzner et al., 2017).

Good management practices, combined with intelligent processes, certainly reduce risks and damage to care. In addition, the use of a management system that favors effectiveness and process management leads to excellence in care when offered. In nursing, good care practices and process management are based on the control of errors and the qualification of care (Báo et al., 2019).

In the healthcare world, where the product offered is the service, this can be a risk factor to life, and the relevance of the aspects that contribute to the best service provision, which includes innovation, becomes a fundamental requirement. When studying hospitals from the point of view of the perception of efficiency, efficacy and effectiveness, it can be said that the work provides useful information for understanding what distinguishes an institution that uses traceability from one that does not use 
it. Although this is not the focus of the work, the nuances of the tools and the equipment used allow us to draw a brief differentiation between those who use certain tools and those who use others. This is how we realize the need for a reliable standard for the process and respective patient safety is urgent, which can benefit the patient and help to act in minimizing errors, contributing to a more effective health in Brazil (Castells, 2017).

In order to establish higher levels of trust, it is necessary for healthcare organizations to understand what needs can help in increasing or restoring trust and confidence in the services offered by healthcare organizations. In this way, to manage a wide range of changes, including the implementation of new or upgraded systems, organizations must have a management system that is intensely based on and that ensures the quality of the operation and its products. Thus, the quality management system must provide the structure of the organization with good conditions to manage the processes, products, and resources with quality, and to find out the responsibility of all those involved (Dias, et al., 2010; Mendonça, 2015).

Improving the efficiency of a hospital is not one of the easiest tasks, nor the fastest. Money, time, training and patience must be spent, often encountering resistance from the organizational culture, which tends to see this apparatus as a kind of surveillance over their daily activities. However, in terms of security, much is gained in improving organizational attendance. The human being commits mistakes that can be previously avoided, if the institution makes efforts to minimize them, but even with arduous training and strong ethical rigor, these health employees are subject to the frantic work day, which is the health field, and to the storms of life that follow. Thus, attention is not enough, it is necessary to have material conditions that make human action more regularized and systematized.

The traceability tools can help the entire health system to be more uniform in the care, in the rendering of accounts, in the inspection, in brief, in the processes. Financing a holistic traceability project is not cheap, even more so if the institution aims at more robust technologies, such as RFID. But even other tools such as barcodes, NFC, Beacons, are extremely efficient to help perform daily activities. It is a fact that the more computerized a health sector is, i.e. those who prescribe and issue reports, coordinate processes and supervise through traceability tools, the better the service conditions will be, more effective and that will satisfy the customer and the manager (Castells, 2017).

Managing a large and specialty hospital is not simple, and seeking a quality standard that aims to reduce or eliminate the error is something that cannot be found only through human commitment, technical mechanisms must be developed that allow the team to minimize and possibly eliminate the error by lack of attention or forgetfulness (Martins \& Waclawovsky, 2015).

It can be said that an emblematic factor of health care is ethics and patient care, but it is not always met because of the large contingent being relegated to poor care, either for lack of care or standardization of practices. Of course, a mechanized service is not the ultimate aim, but a humanized service with rigorous processes, and that allows the user to feel that he is being well attended to without harming his health.

Focusing care on the patient also means giving minimum conditions so that error and carelessness can be fragmented and reduced. And this already represents an advance in terms of quality of care and daily practice. We cannot say that the traceability tool solves all problems, but based on bibliographic research, we can say that it represents an important reason for many institutions to receive the nickname of high-level institutions.

In many countries, where the concern with the process and patient safety is more observed, there is already evidence of widespread use of tools such as RFID, where it is possible, by embedded sensors, even the temperature record, and that allow the integration of data about the patient (Godoy, 2011). This possibility, along with several other advantages, is part of what is called the Internet of Things (IoTs), which promises to be the next revolution in health care, since it will enable 
treatments and monitoring of patients at home, reducing the number of hospitalizations and minimizing spending with the patient (Stevan Jr., 2018). It is the service of the future.

\section{Conclusion}

Technologies such as IoTs and traceability tools are a modern trend in patient care in a way that allows for more personalized and safer care. Automating does not mean dehumanizing, but providing conditions for safer and more controlled care. The patient needs to be sure that his care will be provided in the best possible way, and besides IoTs and traceability tools offering standardization in care, they allow eventual errors to be ascertained more quickly and safely. In this sense, managers end up crediting such tools a higher concept, which lives up to its fame, even recognizing the intangible gains with the adoption. Future studies advocated with greater emphasis on IoTs that seem to be a worldwide trend when it comes to process technologies, management is a robust area of information but one that demands time and patience. Emphasis on organizational intangible gains is believed to be an open space within healthcare for further study.

\section{Acknowledgments}

I thank CAPES for funding the research and subsidizing it, without which it would not have been possible to develop this research.

\section{References}

Báo, A. P., Amestoy, S. C., Moura, G. S., \& Trindade, L. L. (2019). Quality indicators: Tools for the management of best in health. Revista Brasileira de enfermagem, pp. 377-384.

Bhuptani, M., \& Moradpour, S. (2005). Rfid: Implementando o Sistema de Identificação por Radiofrequência. São Paulo: Imam.

Bio, S. R. (1996). Sistemas de informação: Um enfoque gerencial. São Paulo: Atlas.

Boone Jr., H. N., Boone, D. A., \& Virgínia, W. (Abril de 2012). Analyzing Likert data. Journal of Extension, L(2).

Branco, E. A. (2020). O Hospital geral de Salvador (HGeS) e a implantação de um sistema de gestão hospitalar (SGH): Uma análise da melhoria de qualidade. Salvador.

Castells, M. (2017). A sociedade em rede. São Paulo: Paz e Terra.

Colleti Júnior, J., Andrade, A. B., \& Carvalho, W. B. (Maio de 2018). Avaliação do uso de sistemas de prontuário eletrônico nas unidades de terapia inten siva brasileiras. Revista Brasileira de Terapia Intensiva, XXX(3).

Committee on Quality of Health Care in America. (2001). Crossing the quality chasm. Washington: American Psychological Association.

Dias, T. F., Almeida, A. T., Mazzer, G., Murari, M. L., Sousa, F. S., \& Alves, D. (18 de Outubro de 2010). Desenvolvimento de um sistema informatizado de análise e monitoramento de indicadores de qualidade hospitalar-IntegralQI. Anais do XII Congresso Brasileiro de informática em Saúde , pp. 1-7.

Frasson, I. (2001). Critérios de eficiência, eficácia e efetividade adotados pelo avaliadores de instituições não-governamentais financiadoras de projeto sociais. Dissertação de Mestrado, Universidade Federal de Santa Catarina, Departamento de engenharia de produção, Florianópolis.

Godoy, P. C. (2011). Tecnologia RFID: Um proposta de sistematização na gestão hospitalar. Dissertação de conclusão de curso, Universidade de São Paulo, Departamento de Engenharia Elétrica, São Carlos.

Herranz, A., \& Negro, E. (2018). Diretiva Europea de medicamentos falsificados: Luces y sobras para la farmacia hospitalaria. Farmacia Hospitalaria, 43 -44.

Infante, M., \& Santos, M. B. (2007). A organização do abastecimento do hospital público a partir da cadeia produtiva: Uma abordagem logística para a área da saúde. Ciência \& Saúde.

Jones, G. R., \& Jackson, C. (2016). The joint committee for traceability in laboratory medicine (JCTLM) - its history and operation. Clinica Chimica acta, pp. 86-94.

Kumar, S., Tiwari , P., \& Zymbler, M. (2019). Internet of things is a revolutionary approach for future technology enhancement. Journal of big data, pp. 1-21.

La Forgia, G., \& Couttolene, B. F. (2009). Desempenho hospitalar no Brasil: Em busca da excelência. São Paulo: Singular.

Leal, A. N. (2017). Eficência, eficácia e efetividade de auditoria operacional na politica nacional de nefrologia no Distrito Federal. Brasília. 
Liu, Z., Cao, Y., Cui, L., Song, J., \& Zhao, G. (2018). A benchmark database and baseline evaluation for fall detection based on wearable sensors for the Internet of Medical Things Platform. IEEE Acess, pp. 51286-51296.

Machado, J. F. (2018). Fatores que influenciam a notificação de erros de medicação e quase falhas em um Hospital Universitário. Salvador.

Martins, C. C., \& Waclawovsky, A. J. (Janeiro/Junho de 2015). Problemas e desafios enfrentados pelos gestores públicos no processo de gestão em saúde. Revista de Gestão em sistemas de saúde, IV(1).

Maximiano, A. A. (2000). Introdução à administração (5ª ed.). São Paulo: Atlas.

Meirelles, F. S. (2021). Pesquisa Anual do Uso de TI. Rio de Janeiro: FGV-EAESP.

Mendonça, V. S. (2015). O desvelar do sofrimento: A vivência do ser vítima de erro médico. São Paulo: USP.

Metzner, V. V., Silva, R. F., \& Cugnasca, C. E. (2017). Modelo de rastreabilidade de medicamentos utilizando RFID, RSSF e o conceito de internet das coisas. XVIII Congresso de pesquisa e ensino em transporte, (pp. 1-11). Curitiba.

Mota, D. N., Torres, R. M., Guimarães, J. X., Marinho, M. S., \& Araújo, A. F. (Abril/Junho de 2018). Tecnologias da informação e comunicação: Influências no trabalho da estratégia saúde da família. Journal of health informatics, $\mathrm{X}(2)$.

Moura, F. E., Pitta, G. B., \& Tonholo, J. (2020). Prospecção tecnológica de Internet das Coisas no contexto dos hospitais inteligentes. Research, Society and Development.

Nunes, A. A., Mello, L. M., Ana, L. W., Marques, P. M., Dallora, M. E., Martinez, E. Z., . . Coelho, E. B. (2013). Avaliação e incoporação de tecnologias em saúde: processo e metodologia adotados por um hospital universitário de alta complexidade assistencial. Caderno de Saúde Pública .

Pereira, S. R., Paiva, B. P., Souza, P. R., Siqueira, G., \& Pereira , A. R. (2012). Sistemas de informação para gestão hospitalar. Journal of health informatics, $170-175$.

Pinto, C. P. (2016). A rastreabilidade no contexto da gestão da qualidade . Dissertação de Mestrado, Universidade Federal de Itajubá, Departamento de Engenharia da Produção, Itajubá.

Pinto, N. M., \& Coronel, D. A. (2017). Eficiência e eficácia na administração: Proposição de modelos quantitativos. Revista Unemat de Contabilildade, $\mathrm{Vl}(11)$.

Pokorny, M. S. (2017). Proposta de automação e padronização do processo de controle da prescrição médica e dispensação de medicamentos no Brasil baseada no Sistema Autenticador e Transmissor(SAT) aplicado ao controle fiscal do comércio varejista. São Paulo.

Portela, M. C. (2000). Avaliação da qualidade em saúde. Em S. ROZENFELD, Fundamentos da vigilãncia sanitária (pp. 259-269). Rio de Janeiro: Fiocruz.

Ramos, F. M., Parizotto, E. L., Silva, S. A., Ramos , J. M., \& Bampi, G. B. (Dezembro de 2018). Relação entre indicadores de qualidade e econômicos: Um estudo em uma rede de hospitais do terceiro setor do Sul do Brasil. Caderno Saúde Coletiva, pp. 453-461.

Saldiva, P. N., \& Veras, M. (Abril de 2018). Gastos públicos com saúde: breve histórico, situação atual e perspectivas futuras. Estudos avançados, pp. 47-61.

Salu, E. J. (2013). Administração hospitalar no Brasil (1ª ed.). Barueri: Manole.

Sano, H., \& Filho, M. M. (Abril de 2013). As técnicas de avaliação da eficiência, eficácia e efetividade na gestão pública e sua relevância para o desenvolvimento social e das ações públicas. Desenvolvimento em questão(22).

Saúde Business . (12 de Dezembro de 2021). Investimento em tecnologia e medicina baseada em evidência. Fonte: Portal Saúde Business: https://www.saudebusiness.com/voc-informa/investimento-em-tecnologia-e-medicina-baseada-em-evidncia

Silva, A. B., Lima, J. C., Castilho, D. E., Bernardes, C. A., Pires, A. A., \& Nascimento, M. G. (Julho de 2019). Prevenção de erros de medicação por omissão. Boletim ISMP Brasil, VIII(5), pp. 1-8

Silva, C. P., \& Brito, R. R. (2018). Rastreamento de medicamentos na área hospitalar. JNT- Facit Business and Technology Journal, pp. 3-16.

Sonda, M. B. (2018). A rastreabilidade como ferramentas de apoio à gestão em um indústria de plásticos. Caxias do Sul.

Sousa, P., \& Mendes, W. (2019). Segurança do paciente: Criando organizações de saúde seguras. Rio de Janeiro: Fiocruz.

Souza, J. A., Brandão, M. M., Cardoso, A. B., Archer, A. R., \& Belfort, I. P. (Junho de 2020). Comunicação efetiva como ferramenta de qualidade: Desafio na segurança do paciente. Brazilian Journal of health Review, pp. 6467-6479.

Stevan Jr., S. L. (2018). IoT- Internet das coisas: Fundamentos e aplicações em Arduinio e NodeMCU (1ª ed.). (S. C. Ferreira, Ed.) São Paulo: Érica Saraiva.

Van Ornum, M. (December de 2018). Improving bar code medication administration compliance in a community hospital through a nursing leadership iniative. Journal of nursing care quality, pp. 341-347.

Vankipuram, A., Traubb, S., \& Patelac, V. L. (2018). A method for the analysis and visualization of clinical workflow in dynamic enviroment. Journal of Biomedical Informatics, pp. 20-31.

Wamba, S. F., Anand, A., \& Carter, L. (2013). A literature review of RFID-enabled healtcare applications and issues . Information Management. 